\title{
The role of private tutoring in admission to higher education: Evidence from a highly selective university in Kazakhstan
}

\author{
ANAS HAJAR* (1) and SAULE ABENOVA \\ Graduate School of Education, Nazarbayev University, Nur-Sultan, Kazakhstan
}

\section{THEMATIC ARTICLE}

\begin{abstract}
The present mixed-methods study explored first-year undergraduate students of a highly selective university in Kazakhstan's perceptions of having private tutoring (PT) and how far it had helped them gain a place at this university. The quantitative data were collected through a close-ended questionnaire from 144 participants to understand their socioeconomic backgrounds and PT experiences over the previous two years, in terms of the scope, types, costs and the subjects studied in the PT they had received. The subsequent qualitative data were collected through interviewing 8 participants to capture in detail the perceived impact of PT on their overall achievement. The study found that 86 out of 144 participants (60\%) had received PT. Most of them (72\%) had sought PT as an enrichment strategy to obtain higher scores in high-stakes examinations and thus secure a place at that university. Some participants explained the disadvantages of PT, including the financial burden on their families and it being a potentially unfair advantage in a competitive context. The findings of the study are instructive for educators and policy makers in Kazakhstan in revealing the limitations of schooling in the public sector. The pedagogical implications and areas for ongoing research are suggested.
\end{abstract}

\section{KEYWORDS}

private tutoring (PT), high-stakes examinations, access to university, Kazakhstani undergraduate students

\footnotetext{
*Corresponding author. E-mail: anas.hajar@nu.edu.kz
} 


\section{INTRODUCTION}

Globally, higher education enrolment has experienced a vast expansion. This has partly the result of higher birth rates and increased school participation, and the perceived importance of higher education for subsequent life opportunities (Kyvik, 2009). Despite the expansion of the sector, the issue of equity of access to universities has been a major concern in many higher education systems worldwide (Berg, 2020). After more than four decades, Trow's (1973, p. 25) observation of the difficulty of ensuring equitable access to higher education remains relevant: 'the question of the principles and processes of selection and admission to higher education is the crucial point where higher education touches most closely on the social structure'. There are various admission practices in different countries, but most of them are still largely based on university entrance exams (Prakhov \& Sergienko, 2020). Consequently, families competing for access to prestigious higher education institutions for their children, who need to get high scores on high-stakes exams, tend to coach their children themselves, while some hire private tutors. These ambitious families, as Hajar (2019) suggests, hold the view that doing well academically is the clearest path to a better life and so sometimes employ private tutors as a tool to provide additional training in the key subjects required by universities for admission. However, students from disadvantaged households tend to find themselves in a less favourable position because they can afford little or no private tutoring (henceforth, PT) sessions, even with less qualified tutors, adding to their social disadvantage (Prakhov \& Sergienko, 2020). As Bray (2021, p. xi) remarks, PT can be 'a major vehicle for maintaining and exacerbating social inequalities', which raises concerns about how to achieve 'equitable and inclusive quality education'.

PT refers to paying for lessons in academic subjects received outside school hours (Bray, 2020a, p. 100). PT can take various forms, including one-to-one, small-group, live lectures, video-recorded lectures, and online coaching. Recently, PT has received growing recognition from researchers, educators and policymakers because of its potential influence on and implications for issues of social equality, economic growth and the operation of formal education systems (Bray \& Lykins, 2012). This is evidenced by the increasing number of books on the topic (e.g., Bray, 2021; Bray, Kobakhidze, \& Kwo, 2020; Entrich, 2018; Kim \& Jung, 2019) and the number of special issues in scholarly journals, such as Orbis Scholae (Št'astný \& Kobakhidze, 2020), the East China Normal University Review of Education (Zhang \& Bray, 2019) and the European Journal of Education (Györi, 2020). Many families use some form of tutoring at transition points in the formal education system to try to guarantee successful transition to the next level (Hajar, 2018; Ireson \& Rushforth, 2011). One of the key education transition points is from school to university.

In Kazakhstan, the context of the present study, few empirical research studies on PT exist (Akimenko, 2017; Kalikova \& Rakhimzhanova, 2009). In those that do studies, little is known about students' experiences and reflections on them. Although Akimenko (2017) attempted to qualitatively investigate the perceptions of Kazakhstani high school students who had group tutoring in English at one private institute in Nur-Sultan, she did not offer any interview excerpts to capture her participants' perceptions of their PT experience. The mixed-method study reported in this paper attempts to address this research gap by focussing on the fee-paid tutoring that some first-year Kazakhstani undergraduate students received within the previous two years, including preparation for high-stakes entrance examinations to gain places at a university in Kazakhstan with high selection criteria. The entrance to this autonomous government-funded 
university requires an International English Language Testing System (henceforth, IELTS) score of at least 5.5 overall and passing SAT Subject Tests (mathematics, physics, and biology). This paper is organised in four sections. It begins with an overview of previous research on PT in central Asia and its relationship to access to higher education institutions. The objectives of this study are then presented, followed by the rationale for adopting a mixed-methods approach. The third section presents the results from the questionnaire completed by 144 participants and the eight individual semi-structured student interviews. The paper closes with some reflections on the importance of taking account of the impact of PT on social equity, with an emphasis on the importance of establishing a balance and social continuity between the students' lives inside and outside the classroom environment.

\section{REVIEW OF PT RESEARCH AND ITS ROLE IN ACCESS TO HIGHER EDUCATION IN CENTRAL ASIA AND BEYOND}

The phenomenon of PT has long been present in East Asian societies, such as Hong Kong, Japan, and Taiwan, deeply rooted in Confucian culture which values education and diligence for social mobility, including notions of elitism (Yung \& Bray, 2017, p. 99). It has since become endemic in many parts of the world. Nevertheless, Research on PT has not kept up with the global expansion of this phenomenon. This is mainly because PT is less structured, and its prevalence is regarded by some governments as a criticism of the mainstream schooling for which the state is responsible (Zhang \& Bray, 2020). Despite its largely hidden nature, a picture of the scale and intensity of PT in many parts of the world has emerged. As Bray (2020b, p. 3) remarks, rough estimates of $\mathrm{PT}$ 'are part of the jigsaw puzzle which can be used to assemble the picture'. In the Republic of Korea, for instance, $82.5 \%$ of elementary school pupils were estimated to have received PT in 2018 (KOSIS, 2019). In China, 48.3\% of sampled students in a 2017 nationwide survey were engaged in some form of PT (Liu, 2018). Concerning Japan, a 2017 survey showed that $33.7 \%$ of elementary students and $51.9 \%$ of lower secondary students in Tokyo attended tutorial enterprises called juku (Kimura, 2018).

In Central Asian countries, Kazakhstan, Kyrgyzstan, Turkmenistan, Tajikistan and Uzbekistan, the PT market has become increasingly visible since the collapse of the socialist bloc in the early 1990s (Silova, 2010). Reliance on PT in the post-Soviet era is regarded as an effective way for children 'to adapt to the new socio-political realities and cope with post-socialist system changes' (Silova, 2010, p. 328), especially since the majority of students were unfamiliar with the test-based examinations, which then came into use. It was believed that, like other skills, personal knowledge could be purchased. The few studies on PT in Central Asia reported in Silova's (2009) edited book showed that more than 50\% of the students sampled had participated in some type of PT during the final grade of secondary school. More specifically, the scale of PT varied according to country; $64.8 \%$ of all students surveyed had received PT in Kazakhstan (Kalikova \& Rakhimzhanova, 2009), with 60\% in Tajikistan (Kodirov \& Amonov, 2009), and $52.5 \%$ in Kyrgyzstan (Bagdasarova \& Ivanov, 2009). In Uzbekistan, a recent study was conducted by Khaydarov (2020) on 109 Grade 12 students in two selective schools about their PT experiences over the previous 12 months. Khaydarov (2020) found that $95 \%$ of students had received PT, mainly to help them prepare for state university examinations (97\%), followed by 
understanding their subjects better (42\%) and improving their examination marks in their current schools (23\%).

In Kazakhstan, the context of the present study, Kalikova and Rakhimzhanova's (2009) quantitatively examined the PT experience of 1,004 first-year university students from the six largest state universities in the cities of Almaty and Shymkent in the last year of secondary schooling. They reported that $59.9 \%$ of students had received tutoring (private lessons, preparatory courses, or both), to prepare for university entrance examinations (42\%). The students surveyed in Kalikova and Rakhimzhanova's (2009) study mentioned other reasons for having PT, including to improve their understanding of the subjects taught at schools (31\%), to fill knowledge gaps $(26 \%)$ and to compensate for the low quality of education in mainstream schools (11\%). Kalikova and Rakhimzhanova (2009, p. 103) also found that the most popular PT subjects were mathematics (67\%), history (36\%), physics (36\%), and the Kazkah language and literature (17\%), given that mathematics, history and the Kazakh language are compulsory subjects in the Unified National Test (UNT), a high-level entry test for most Kazakhstani universities. Therefore, the UNT is highly tutored. The UNT is structured into two blocks: the first consists of compulsory tests in the history of Kazakhstan, mathematical literacy, and reading literacy; the second block comprises examinations in the two specialist subjects of the applicant's choice (Chankseliani, Qoraboyev, \& Gimranova, 2020). However, the UNT is not considered part of the admission process for access to the university the participants of the present study competed to attend. As already mentioned, the assessment tests required are the IELTS and SAT Subject Test (mathematics, physics, and biology). Although Kazakhstan has attempted to turn its back on 'the Soviet-style, corrupt system of university-based admissions and the establishment of centralised examinations for student selection' (Chankseliani et al., 2020, p. 996), the centralised examinations in Kazakhstan make access to university 'more competitive, and the private tutoring market has been quick to take advantage of this situation' (Kalikova \& Rakhimzhanova, 2009, p. 98). Related to this, Carlsen (2020, p. 19) suggests that the PT phenomenon has expanded in Central Asia mainly due to central testing system, low salaries in the formal system and increasing demands for access to prestigious higher education institutions. Carlsen (2020, p. 20), therefore, argues that PT in Central Asia can contribute to 'increasing social inequities, distorting curricula, inviting corruption, and depriving the state of tax revenues'.

Although the above few quantitative studies have given some insights into the reasons for the prevalence of PT in central Asia and its impact on students' access to universities, students' voices and critical reflections on their PT experiences remain few (e.g. Akimenko, 2017). The present paper adds to this knowledge by reporting first-year Kazakhstani engineering students' views of the PT they had participated in before their studies, using both quantitative and qualitative data. The participants in the current study came from a highly ambitious university with the best results among Kazakhstani higher education institutions.

\section{STUDY DETAILS}

\section{Aims}

The purpose of this mixed methods research is to unravel the association between receiving PT and access to a prestigious university in Kazakhstan, based on the voices of first-year 
undergraduate students. Giving students a voice, the opportunity to reflect on their experiences of PT, is at the heart of the present study. Without capturing students' perceptions and out-ofschool experiences, teachers, researchers and policymakers only have access to a partial picture of students' actual learning experiences and achievements. This study is guided by the following research questions:

1. What are the quantities, types, subjects and costs of PT received by the sampled participants in the preceding 24 months?

2. How do the participants evaluate their PT experience?

\section{Participants}

The present study focused on first-year undergraduate students because, as Silova, Bray, and Zabulionis (2006, p. 63) suggest, their memories of their PT at secondary school are relatively fresh and they are less likely to feel uncomfortable reflecting on it. The students selected were from the Engineering Department since they were more likely to have received PT than students from other departments (e.g., Department of History and Religious Studies, Department of Languages and Literature, Department of Sociology and Anthropology, and Department of Economics) due to the high level of competition for course entrance. All were citizens of Kazakhstan and not known to the researchers prior to collecting the data. Initial access to the participants was through the help of two members of the administrative staff in the Engineering Department following a meeting between them and the researchers. The researchers explained the significance and the purpose of the study, together with the participants' rights, in the meeting.

\section{Data collection and analysis}

The quantitative data were collected using a close-ended survey (see Appendix A). The survey sought to elicit certain dimensions of PT, including the scope and, types of PT, its prevalence, subject choices and parental expenditure before the students' acceptance at the target university. Initially the survey questionnaire was developed in English and then translated into Russian and Kazakh. In January 2020, one of the administrative staff sent an email to the first-year undergraduate students in the Engineering Department with a link to the survey designed in Qualtrics. The survey remained available online for nearly two months (January-February 2020), in order to obtain a sufficient completion rate for analysis. A total of 144 out of the targeted 226 students, whose ages ranged between 18 and 20 years old completed the survey questionnaire, making a response rate of $63 \%$. The survey was field-tested, revised and field-tested again with 40 participants who had PT experience. The process of piloting the survey was to assess the appropriacy relevance of each item to measure the construct it was intended to measure, and the clarity of the items.

Informed consent was given in the first part of the survey. Those that took the survey were over the age of 18 and willing to participate in the research. Table 1 shows some demographic characteristics of the survey participants. Approximately the same number of males and females composed the sample ( $48.6 \%$ male, $43.1 \%$ female, with the exclusion of 12 participants who did not respond to the question relating to their gender and origins). 
Table1. Demographic characteristics of the participant sample

\begin{tabular}{lccrrr}
\hline & \multicolumn{2}{c}{ Gender } & & \multicolumn{2}{c}{ Origin } \\
\cline { 2 - 3 } \cline { 5 - 6 } & Male & Female & & Urban & Rural \\
\hline Sample & $70(48.6 \%)$ & $62(43.1 \%)$ & & $124(86.1 \%)$ & $8(5.6 \%)$ \\
Sample size: & $132 ;$ & Missing: 12 & & \\
\hline
\end{tabular}

The final item of the survey asked the respondents to write their email address if they were willing to participate in an individual semi-structured interview. Eighteen students expressed their initial willingness to take part in follow-up interviews. An email was sent to these participants in Kazakh, Russian and English about the aims of the study, their rights and the requirements of their participation in the interview part. Only 8 students ( 3 males and 5 females) responded to this email. The second researcher who is a research assistant to the first researcher of the paper is Kazakh and speaks the same languages (Kazakh and Russian) as the participants, so she organised with the participants through mobile calls and text messages, a suitable time and place for the interviews. One semi-structured, in-depth interview with each participant was conducted. The researchers had an interview schedule to keep them on track, but could ask questions with some flexibility during the interviews. The interview data were in Kazakh or Russian, according to the participants' preferences, so that they could express their ideas clearly and with confidence. They mainly focused on the participants' reported motives for taking part in PT, along with its benefits and disadvantages, from the participants' perspectives. Each interview lasted approximately an hour and took place in a private room on the university campus. With the participants' permission, all the interviews were audiotaped and transcribed (see Appendix B for a sample of interview questions).

Clarke and Braun's (2013) systematic guidelines for conducting thematic analysis were adopted to analyse the semi-structured interviews conducted with the participants. Thematic analysis is 'a method for identifying and interpreting patterns of meaning (themes) across qualitative data' in rich detail (Clarke \& Braun, 2013, p. 218). The researchers familiarised themselves with the data through reading and rereading the interview transcripts 'actively, analytically and critically' after the transcripts had been translated into English (Clarke \& Braun, 2013 , p. 205), to discover both the surface and hidden meanings of the participants' responses. After the process of familiarisation, the data were grouped to generate the initial codes, particularly in response to the second research question. For this purpose, a 'selected reading approach' (Van Manen, 1997, p. 93) was used; as the researchers read the transcripts, they highlighted the statements that captured the participants' evaluation of PT. After that, codes that shared features in general were collated to generate themes. Two core themes were identified: 'motives for having PT' and 'evaluation of receiving PT'. The tentative themes derived from the coded data and the entire data set were tested. Once all the themes had been found, the subthemes within each main theme were identified.

\section{FINDINGS AND DISCUSSION}

This section commences by addressing the first research question and presenting the descriptive data on the demographic characteristics of the sampled participants, together with the scale, 
types, subjects and costs of the PT that the participants received. It then turns to answer the second research question related to the participants' evaluation of their PT experiences. The qualitative interview data obtained from 8 interviewees were mainly used to analyse the responses to the second question of the study.

\section{RQ 1 WHAT ARE THE QUANTITIES, MODES, SUBJECTS AND COSTS OF THE PT RECEIVED BY THE SAMPLE OF PARTICIPANTS OVER THE PREVIOUS 2 YEARS?}

\section{Geographic and educational inequalities to higher education access}

As shown in Table 1, 124 out of 132 participants (86.1\%) came from urban areas, whereas only 8 participants (5.6\%) were from rural areas. As previously mentioned, the survey respondents were 144, but 12 did not answer the questions relating to their gender and origin. These figures align with Chankseliani et al.'s (2020) suggestion that rural school graduates in Kazakhstan are less likely to take part in the central examination system than urban school graduates to secure a place at one of the Kazakhstani universities. Chankseliani et al. (2020) made this claim with reference to the National Testing Centre (NTC) survey of Kazakhstan in 2018. According to this survey, there were 146,034 school graduates in 2018, 72,746 of whom finished their schooling in rural areas; if all rural school graduates applied to higher education, only $12 \%$ could expect to obtain a state grant (cited in Chankseliani et al., 2020, p. 1001). The same survey by the NTC of Kazakhstan (2018) showed that 54\% of students from Nur-Sultan, the capital of Kazakhstan, obtained state grants, whereas only $24 \%$ of students from rural areas succeeded in obtaining state grants (cited in Chankseliani et al., 2020, p. 1001). Some previous studies (e.g. Bray \& Kwo, 2014 in Hong Kong; Kim \& Lee, 2010 in South Korea; Liu \& Bray, 2017 in China; and Mahmud \& Bray, 2017 in Bangladesh) have also showed that the coverage of PT is likely to be higher in urban areas than in rural areas.

The distribution of the participants according to their educational and geographical characteristics is shown in Table 2. The overwhelming majority of the participants graduated from schools located in the most populated cities of Kazakhstan, namely Nur-Sultan (formerly Astana) (n.44), Almaty (n.29) and Shymkent (n.24). Interestingly, most of the participants had graduated from 'elite' secondary schools such as Nazarbayev Intellectual Schools (NIS), Bilim Innovation Lyceums (BIL), Physics-Mathematics State Schools (PMSS), Boarding School Daryn (BSD), School for gifted children Zerde (SGCZ), in addition to other lyceums and gymnasiums.

Table 2. Educational and geographical characteristics of the sample

\begin{tabular}{lrrrcrr}
\hline & NIS & BIL & PMSS & SGCZ & BSD & MS \\
\hline Total & 48 & 28 & 13 & 3 & 4 & 48 \\
Nur-Sultan & 9 & 8 & 5 & 2 & 3 & 17 \\
Almaty & 10 & 3 & 6 & 1 & & 9 \\
Shymkent & 17 & 3 & & & & 4 \\
Other cities & 12 & 14 & 2 & & 1 & 18 \\
\hline
\end{tabular}




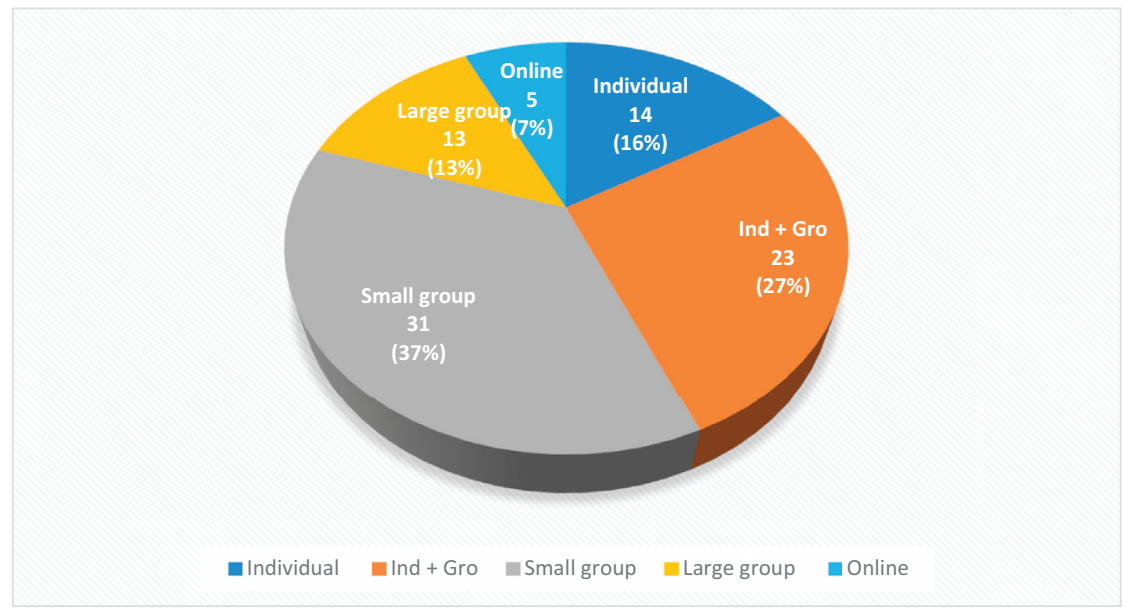

Fig. 1. Modes of PT delivery

Hence, the ratio of elite school graduates to other regular/mainstream school (MS) graduates who gained places at this highly competitive university is $66.7 \%-33.3 \%$.

\section{The scope and mode of delivery of PT}

The quantitative data also showed that the scope of PT within the survey population surveyed was almost $60 \%$ (86 out of 144), meaning that three out of five applicants had gained university placement having had PT. This result resonates to an extent with that of Kalikova and Rakhimzhanova (2009), who found that a large number of first-year university students in Kazakhstan had used PT to help them prepare for high-stakes examinations (42\%).

As regards the modes of PT delivery, half the participants took PT lessons in groups, with $37 \%$ of students studying in groups of less than 10 students and $13 \%$ of students studying in groups of 10 or more students (see Fig. 1). 23 out of 86 participants (27\%) reported that they received both individual and group tutoring, while 14 participants (16\%) had one to one tutoring. This finding aligns with that of Silova (2009, p. 74), who found that over $40 \%$ of students in Central Asia opted to have PT in groups because it was more affordable than individual tutoring for many households, and group tutoring may be more profitable for both private tutors and tutoring companies. Only 5 participants (7\%) had received online tutoring; however, more students are likely to have online tutoring during the COVID-19 pandemic. As Zhang and Bray (2020) point out, with the global outbreak of COVID-19 at the beginning of 2020 'many face-to-face tutoring enterprises closed alongside schools but ones employing technology for distance learning experiencing a sudden boom'.

\section{Subjects, number of hours and costs of PT}

The subjects studied by individual participants according to the questionnaire survey varied, but overall, the participants studied nine subjects. As shown in Fig. 2, the vast majority of respondents reported receiving PT in English language (n.35). They also took PT in Maths (n.21), 


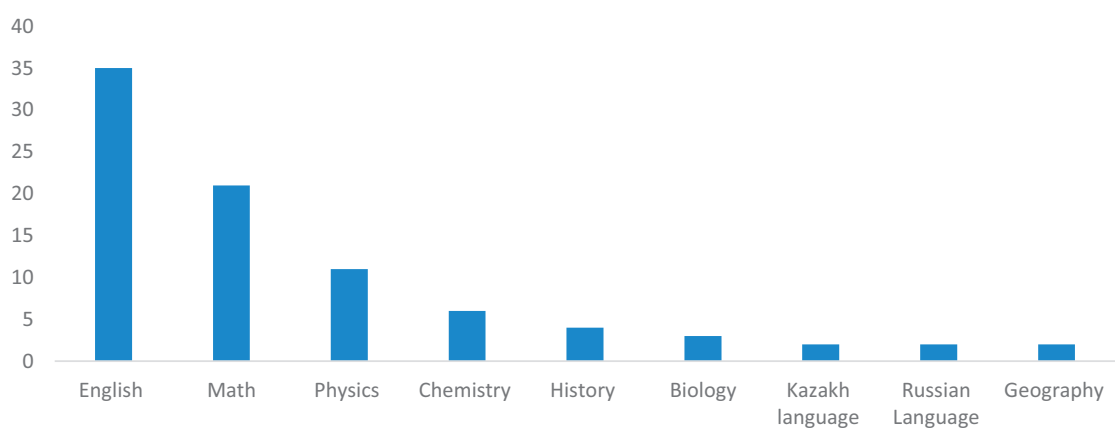

Fig. 2. Number of participants in PT according to subject

Physics (n.11) and chemistry (n.6), history (n.4), biology (n.3), the Kazakh language (n.2), geography (n.2) and Russian language (n.2). These results are different from those of Kalikova and Rakhimzhanova (2009) who found that their first-year university participants took PT mainly in mathematics (67.2\%), followed by history (36.2\%), physics (36\%) and the state language and literature (17.8\%). This discrepancy can be explained by the fact that subjects in demand for PT are predominantly those that are crucial at the transition points (Bray \& Kwo, 2013; Hajar, 2019). The participants in Kalikova and Rakhimzhanova's (2009) study needed to excel in the UNT test, which includes mathematics, history and the state language and literature. Conversely, the participants in the present study applied for a highly selective university in Kazakhstan, whose entrance examinations require high proficiency in English and mathematical skills. Therefore, these subjects were the subjects in demand for PT from the participants. Notably, 4 questionnaire completers had received PT in history, which might be because they had planned to take the UNT to enrol in other Kazakhstani universities if they failed to secure a place at their first choice of university. In a follow-up interview one student said that in my Grade11, I had tutoring sessions in Maths, English and history because my mother wanted me to prepare for both the UNT and SAT tests' (Participant 5).

In terms of the number of PT hours received, the majority of the respondents (n.59) indicated that they had received $12 \mathrm{~h}$ of PT or less per month, while a slightly fewer number of respondents (n.48) reported having received 13-24 h of PT per month. Only 7 participants indicated that they had taken 25-36 h of PT over a one-month period. The most intensive number of PT hours was 37, taken by 8 participants. What can be clearly observed in Table 3, below, is that the number of PT participants increases with lower costs and decreases as costs

Table 3. Average cost of PT per month and number of hours of PT received per month

\begin{tabular}{lcccccc}
\hline & \multicolumn{5}{c}{ Average cost of PT per month } \\
\cline { 2 - 7 } Hours & 20 k-or less & $21 \mathrm{k}-40 \mathrm{k}$ & $41 \mathrm{k}-60 \mathrm{k}$ & $61 \mathrm{k}-80 \mathrm{k}$ & $81 \mathrm{k}-90 \mathrm{k}$ & $100 \mathrm{k}->$ \\
\hline $12 \mathrm{~h}$ or less & 21 & 25 & 7 & 3 & 0 & 3 \\
$13-24 \mathrm{~h}$ & 14 & 16 & 12 & 4 & 1 & 1 \\
$25-36 \mathrm{~h}$ & 1 & 0 & 2 & 2 & 0 & 1 \\
$37 \mathrm{~h}$ and more & 0 & 2 & 1 & 2 & 1 & 2 \\
\hline
\end{tabular}


rise. This reverse association between the number of hours per month and the cost of PT per month demonstrates that participants favour time over costs. In other words, participants in PT seem to prefer to pay less per month because they can have more PT sessions. With higher costs, the number of hours attended are fewer, which suggests that high prices for PT were not favoured by the participants.

Overall, there is no clear indication whether the cost of PT impacted on the number of hours participants were able to take. However, looking at the distribution of costs per month, it seems that those who paid less per month received more PT hourly sessions than those who paid higher prices. That is, those who paid between 46 USD (20,000 KZT) and 93 USD (40,000 KZT) per month had had more hours of tutoring (n.82). The number of those who paid between 95 USD (41,000 KZT) and 232 USD (100,000 KZT) was approximately half that of those who paid less (n.41).

\section{RQ 2 HOW DO THE PARTICIPANTS EVALUATE THEIR PT EXPERIENCE?}

This section provides the findings on the participants' motives for having PT, together with their perceptions of the advantages and disadvantages of having PT based on their PT experiences. Figure 3 presents the thematic map from the analysis of qualitative data.

\section{Motives for having PT}

The results of the descriptive analysis of the frequency of the reasons for having PT are provided in Table 4. The most common reason the respondents gave was that they took PT to prepare for university examinations (72\%). The data also showed that $42 \%$ of the respondents received tutoring with the aim of improving examinations marks in school exams, and $23 \%$ of the

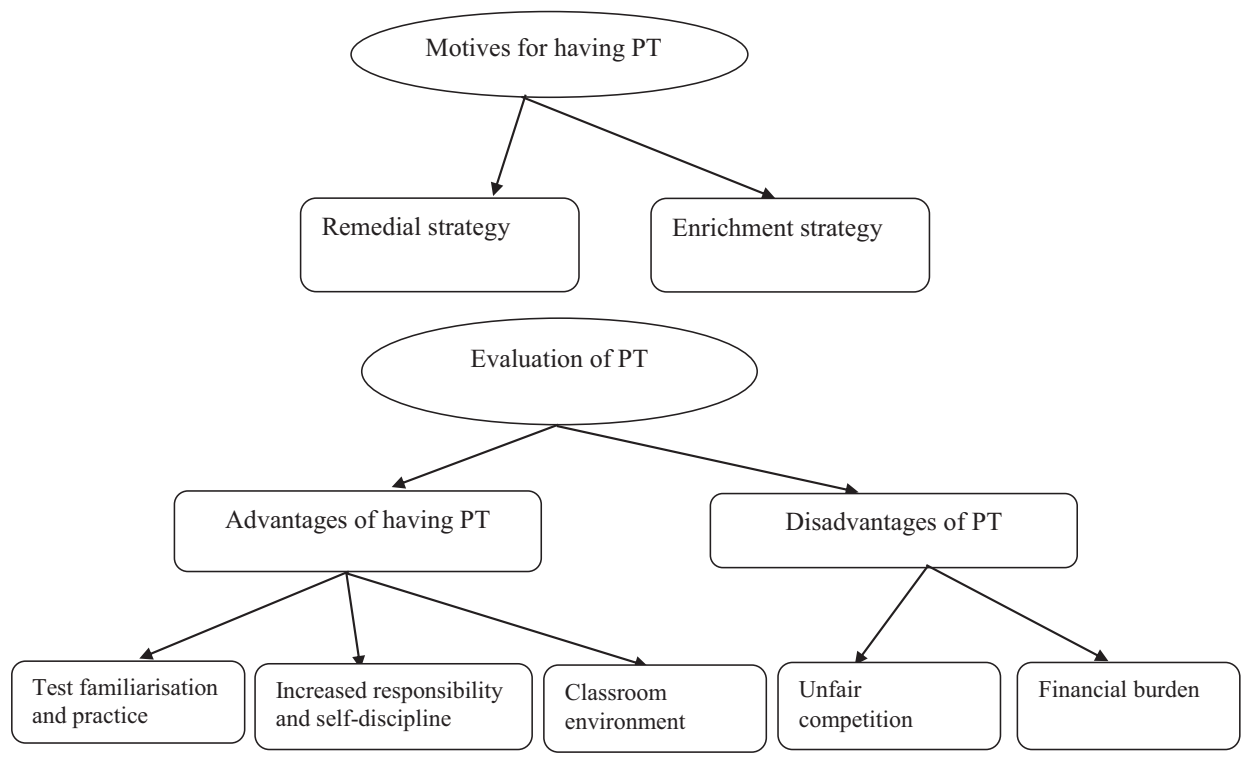

Fig. 3. The final thematic map derived from students' interview data 
Table 4. Numerical data of reasons for having PT

\begin{tabular}{lcc}
\hline Reasons & Frequency $(n=86)$ & Percent \\
\hline $\begin{array}{l}\text { I was preparing for university entrance } \\
\quad \text { exams }\end{array}$ & 62 & $72 \%$ \\
I wanted to improve my exam scores at & 36 & $42 \%$ \\
$\quad$ school & & \\
I wanted to learn subjects better & 20 & $23 \%$ \\
My parents chose it for me & 14 & $16 \%$ \\
Many of my classmates were doing it & 8 & $9 \%$ \\
Other reasons & 5 & $6 \%$ \\
My teachers recommended it & 4 & $4 \%$ \\
\hline
\end{tabular}

students wanted to understand their subjects better. On the other hand, other reasons such as parental demands, teacher recommendations and doing what friends did, had no significant impact on students choosing to have PT.

The interview data collected from 8 interviewees revealed the use of PT as an enrichment and/or remedial strategy. Silova (2009) pointed out that PT as an enrichment strategy implies using PT to gain educational advancement opportunities at light of high competition levels, which can be achieved according to good results in high-stakes examinations. Conversely, PT as a remedial strategy implies PT for students whose academic performance does not meet the minimal requirements of schooling and hence needs to be improved (Silova, 2009). The data analysis shows that all the interviewees received PT as an enrichment strategy, i.e. as a preparation for the high-stakes entrance examination to win a place at their chosen university in Kazakhstan. These high-stakes examinations are IELTS and SAT tests. The following extracts exemplify this point:

\section{Extract 1:}

Interviewer: Why did you have private tutoring in the last two years?

Participant 2: I attended the IELTS preparation course to enter this university. My English level was not up to the level of this university.

Participant 3: I was preparing for the final school examinations and I also wanted to prepare for the university entry examination.

Participant 5: I had private tutoring for six months to prepare for the IELTS and SAT tests. My mother asked me to prepare for the UNT test instead, but I insisted as I wanted to attend this leading university in my country.

Participant 7: When I tried to do the IELTS test, I saw that my English level was low. Therefore, I decided to attend English courses. I also attended Maths and Physics for the SAT test.

This finding does not concur with Akimenko's (2017) qualitative investigation of the perceptions of Kazakhstani high school students who had received group tutoring in English at a private institute in Nur-Sultan, the capital of Kazakhstan. Akimenko (2017) found that her participants had received PT in English for mainly remedial purposes, to increase their English vocabulary and improve their understanding of certain grammar concepts that they had been unable to grasp at school. The analysis of the interview data in the present study found that three 
interviewees had received PT not just for enrichment purposes, but to catch up to the level of their classmates and fulfil the general requirements of mainstream schooling (i.e., for remedial purposes). Extract 2 taken from the interview of Participant 4 refers to this idea.

\section{Extract 2:}

Participant 4: I had tutoring sessions in Maths and Physics in Grade 11 because these subjects were complicated and taught in English...my parents suggested having tutoring to me to catch up with my peers.

\section{Advantages and disadvantages of PT}

This section now examines the benefits and disadvantages associated with PT from the 8 interviewees' perspectives. As shown in Table 5, all the interviewees found PT useful for coaching for the university entrance exams, namely IELTS and the SAT Subjects Test (mathematics, physics, and biology). They felt that private tutors had helped them be more committed to achieving their main goal of attending this highly selective university, by having extensive practice similar test items along with learning certain techniques to help them answer the questions. This was mainly because 6 out of 8 interviewees mentioned that they were not trained in how to take these high-stakes exams through their secondary schooling. Two interviewees (2 and 5) who had attended Nazarbayev intellectual schools stated that IELTS preparation was included in the curriculum of their schools, but they still needed PT to have more practice in the IELTS and SAT tests. It can be inferred that all interviewees articulated the tangible benefits of $\mathrm{PT}$ in terms of measurable educational outcomes. This finding seems to concur with Bray and Kwo's (2014, p. ix) suggestion that PT tends to put emphasis largely on one dimension of education: 'learning to know' more than the other pillars proposed by the UNESCO Delors Report (1996), which included learning to do, learning to be, and learning to live together. Bray and Kwo (2014) attributed this to the overemphasis on high-stakes examinations functioning as principal gate-keeping mechanisms.

As can be seen in Table 5, the interviewees shared their views about the disadvantages of receiving PT; namely, creating a financial burden on the family and changing the level of the playing field. Apart from participant 6, the other participants acknowledged that although gaining a place at this highly selective university in Kazakhstan is perceived as a huge achievement, they would not be able to pass the university entrance exams without the help of their private tutors. Related to this, two interviewees (Participants 2 and 3) questioned the issue of equity of access to this university since some students did not enjoy the privilege of PT (see Table 5). They mentioned that PT exacerbates social inequalities and widens the intellectual gap between those who can afford PT and those who cannot. This has been found by Hajar (2018, 2019) in England, Silova (2009) in Central Asian countries, and Loyalka and Zakharov (2016) in Russia. Loyalka and Zakharov (2016), for instance, found that more than $50 \%$ of the sampled students participated in PT in Russian language and mathematics because the scores of these two subjects were considered for college admissions. They also reported that PT gave high-achieving students an additional advantage over low-achieving students who were competing to enter college and elite colleges. Since PT only benefited high-achieving students who were also from high socioeconomic backgrounds, it contributed to greater educational inequality. 
Table 5. Advantages and disadvantages of PT from the students' perspectives

\begin{tabular}{|c|c|}
\hline Advantages of $\mathrm{PT}$ & Disadvantages of PT \\
\hline $\begin{array}{l}\text { Test familiarisation and practice } \\
\text { I had many mock IELTS tests, but my score didn't } \\
\text { exceed 5. Therefore, I hired a private tutor to train } \\
\text { me in the IELTS test for five months. . She taught } \\
\text { me many effective strategies for the IELTS test, and } \\
\text { this helped me obtain Band } 6 \text { in IELTS. } \\
\text { (Participant 7) } \\
\text { In the 11th Grade I recognised that it was essential } \\
\text { to have tutoring to prepare myself for the } \\
\text { university entrance exams. Therefore, I had group } \\
\text { tutoring for IELTS preparation, and then I had } \\
\text { tutoring in Maths to pass the SAT Subjects } \\
\text { Test. ...I learnt to solve problems much faster and } \\
\text { see the solutions to the equations at once. Without } \\
\text { tutoring, it is very difficult to pass this test } \\
\text { (Participant } 4 \text { ) } \\
\text { At school IELTS lessons were not enough, so I had } \\
\text { to take PT, because my English level was not good } \\
\text { enough to pass the university entrance exam. For } \\
\text { this reason, I had to take additional sessions. } \\
\text { (Participant 2) } \\
\text { Increased responsibility and self-discipline } \\
\text { I am sometimes lazy. My tutor helped me organize } \\
\text { my time and be more disciplined by giving me } \\
\text { strict deadlines to complete tasks in preparation } \\
\text { for the university test. He motivated me to see my } \\
\text { progress. (Participant } 8 \text { ) } \\
\text { Classroom environment } \\
\text { In private tutoring, every student is given more } \\
\text { time, because there are fewer people. There were } \\
\text { more than } 30 \text { students in the class. With } 3-4 \\
\text { students, we learnt faster and it's more convenient. } \\
\text { Everything was clear. (Participant } 1 \text { ) }\end{array}$ & $\begin{array}{l}\text { Changing the level of the playing field } \\
\text { I believe that private tutoring extends the } \\
\text { intellectual stratification between students who } \\
\text { can afford it and those who cannot. . In } \\
\text { Kazakhstan, many families cannot afford } \\
\text { private tutoring and thus students might not } \\
\text { pass the exams required to study at this } \\
\text { university. . . some procedures for helping } \\
\text { lowincome families should be created. } \\
\text { (Participant 3) } \\
\text { Without private tutoring, I could not get the } \\
\text { required score for the IELTS exam to join this } \\
\text { university. (Participant } 2 \text { ) } \\
\text { Create a financial burden } \\
\text { I had to work hard with my private tutors } \\
\text { because my parents paid a lot of money. It also } \\
\text { consumed my time (Participant 5) } \\
\text { The university entrance tests on Chemistry } \\
\text { and Biology were combined, but I had to study } \\
\text { Biology and Chemistry separately, paying a lot } \\
\text { of money... tutoring sessions are expensive, } \\
\text { and their high prices prevent many students } \\
\text { from taking them. (participant } 6 \text { ) }\end{array}$ \\
\hline
\end{tabular}

\section{CONCLUSION AND IMPLICATIONS}

The overarching aim of this mixed-methods study reported was to find the association between PT participation and access to a highly selective university from the experiences and perspective of first-year Kazakhstani undergraduate students. The study suggests urban school graduates, the majority of the study participants, were those who had sufficient financial resources to attend PT to help them prepare for the entrance examination and win a state grant to a highly selective university in Kazakhstan. In Kazakhstan, as in many countries, state tuition grants are very competitive and only about a quarter of all students enrolling are awarded a full or partial grant (Chankseliani et al., 2020; OECD, 2017). This has impacts on both social and economic 
inequality because not all students or their parents can afford PT, especially those living in rural areas. One way to help rural school graduates enter prestigious universities in their countries is 'the contextual admissions approach' (Chankseliani et al., 2020, p. 1007) by considering applicants' geographical origins for higher education selection. The findings of this study support the argument that most families realise the need to invest at the senior-secondary level to secure state tuition grants for support their children at tertiary level. That is, although PT coaching to pass high-stakes exams and to secure state grants at that highly selective university constitutes a financial burden for many families, it is more affordable and effective than enrolling in Kazakhstani Universities which charge high tuition fees. Accordingly, policies that increase the number of students admitted to elite institutions and enhance the quality of public institutions could be explored.

As the phenomenon of PT has expanded to reach almost all corners of the globe, be absorbed into the education culture and gained 'more pragmatic and normative legitimacy' (Zhang \& Bray, 2020, p. 331), it would be hard and unrealistic to eliminate or ban it altogether. Consequently, some governments have attempted to regulate PT markets by introducing codes of practice (see Bray, Kobakhidze, \& Kwo, 2020; Bray \& Kwo, 2014; Zhang \& Bray, 2020). In China, for instance, one of the regulatory PT mechanisms means that tutorial companies are prohibited from covering the official school curriculum in advance, to protect schools and take the pressure off students from a disadvantaged background who cannot seek PT to catch up with their classmates (Zhang \& Bray, 2020). However, In Kazakhstan, the context of this study, the government's attempt to regulate the PT market has largely been confined to asking private tutors to purchase a license and pay taxes to legally offer PT (Silova, 2010). However, most tutors are reluctant to declare their additional income, considering it a necessary survival strategy. Silova (2010, p. 340) asserts that imperfect legislation, lack of implementation mechanisms, and absence of legal enforcement' describes the PT market in central Asian countries. Zhang and Bray (2020, p. 331) suggest enhancing the partnership between the authorities and 'schools, teachers' unions, other government branches, community bodies, and the media' to develop a regulatory policy. Zhang and Bray (2020) point out how an online tutoring company in the US, emphasising grades and admission to higher education, provides free tutoring to military families funded by the US Department of Defense and the Coast Guard Mutual Assistance. In addressing the issue of equitable access to schools and universities, Kirby (2016) also suggests that the UK government could expand non-profit and state tuition programmes such as the Tutor Trust, to offer the advantages of tutoring to more disadvantaged students.

While the current study has provided some evidence of the importance of understanding the link between PT and access to higher education from the students' point of view, it has limitations. In particular, it was a small-scale study and relied only on questionnaire data collected from 144 students in Engineering followed by interviews with 8 students, all from one university in Kazakhstan. Hence, future large-scale studies which include the perceptions of students with and without tutoring, from different disciplines, together with the viewpoints of parents and practitioners, would enrich the database. An area of the field of PT worthy of additional research relates to understanding the nature and effectives of online PT during the COVID-19 pandemic, which has affected educational systems worldwide, leading to the near-total closures of schools, universities and colleges. As Št'astný and Kobakhidze (2020, p. 10-11) suggest, 'attention must also be given to emerging new forms of tutoring such as "education pods", "Zutors" (i.e. Zoom 
tutors) and "microschools", which have been pushed by parents' initiatives worldwide as a result of the pandemic.'

Funding: This project is supported by the Nazarbayev University Graduate School of Education [064.01.00/201705 SPG (Social Policy Grant)].

\section{ACKNOWLEDGEMENTS}

The authors would like to acknowledge the assistance provided by Professor Mark Bray at the University of Hong Kong and to thank the two anonymous reviewers and the editors for their insightful comments and editorial support.

\section{ABOUT THE AUTHORS}

Anas Hajar is a graduate of Warwick University holding a PhD in English Language Education. He worked as a Postdoctoral Research and Teaching Fellow at Warwick, Coventry and Christ Church Universities in the UK and at the Chinese University of Hong Kong in Hong Kong SAR. $\mathrm{He}$ is currently an Assistant Professor of Multilingual Education at Nazarbayev University in Kazakhstan. He is particularly interested in motivational issues in language learning and intercultural engagement. He also works in the areas of internationalization and education abroad, language learning strategies and shadow education.

Saule Abenova holds a master's degree in multilingual education. She is particularly interested in individual differences in second language learning and shadow education.

\section{REFERENCES}

Akimenko, O. (2017). Investigating the effectiveness of private small group tutoring of English in Kazakhstan: Perceptions of tutors and students. NUGSE Research in Education, 2(1), 16-26.

Bagdasarova, N., \& A. Ivanov. (2009). Private tutoring in Kyrgyzstan. In I. Silova (Eds.), Private supplementary tutoring in Central Asia: New opportunities and burdens (pp. 119-142). Paris: UNESCO International Institute for Educational Planning (IIEP).

Berg, G. A. (2020). Equity and diversity in the 21st century university: A literature review. In G. A. Berg, \& L. Venis (Eds.), Accessibility and diversity in the 21st century university (pp. 1-19). Pennsylvania: IGI Global.

Bray, M. (2020a). Shadow education: Scale, drivers and future directions in the global spread of private supplementary tutoring (pp. 100-104). Humanistic futures of learning, Paris: UNESCO.

Bray, M. (2020b). Shadow education in Europe: Growing prevalence, underlying forces, and policy implications. ECNU Review of Education, 2096531119890142.

Bray, M. (2021). Shadow education in Africa: Private supplementary tutoring and its policy implications. Hong Kong: Comparative Education Research Centre, The University of Hong Kong and Paris: UNESCO. 
Bray, M., Kobakhidze, M. N., \& Kwo, O. (2020). Shadow education in Myanmar: Private supplementary tutoring and its policy implications. Hong Kong: Comparative Education Research Centre, The University of Hong Kong and Paris: UNESCO.

Bray, M., \& Kwo, O. (2013). Behind the façade of fee-free education: Shadow education and its implications for social justice. Oxford Review of Education, 39(4), 480-497. https://doi.org/10.1080/03054985.2013. 821852.

Bray, M., \& Kwo, O. (2014). Regulating private tutoring for public good: Policy options for supplementary education in Asia. Bangkok: UNESCO and Hong Kong: Comparative Education Research Centre, The University of Hong Kong.

Bray, M., \& Lykins, C. (2012). Shadow education: Private supplementary tutoring and its implications for policy makers in Asia. Mandaluyong City: Asian Development Bank and Hong Kong: Comparative Education Research Centre, The University of Hong Kong.

Carlsen, A. (2020). Ensuring lifelong learning for all in Kazakhstan, Kyrgyzstan, Tajikistan and Uzbekistan: Country evidence and policy recommendations. Paris and Almaty: UNESCO.

Chankseliani, M., Qoraboyev, I., \& Gimranova, D. (2020). Rural disadvantage in the context of centralised university admissions: A multiple case study of Georgia and Kazakhstan. Compare: A Journal of Comparative and International Education, 1-19. https://doi.org/10.1080/03057925.2020.1761294.

Clarke, V., \& Braun, V. (2013). Successful qualitative research: A practical guide for beginners. London: Sage.

Delors, J. (1996). Learning: The treasure within. Report to UNESCO of the international commission on education for the twenty-first century. Paris: UNESCO.

Entrich, S. (2018). Shadow education and social inequalities in Japan. Evolving patterns and conceptual implications. Heidelberg: Springer.

Győri, J. G. (Ed.). (2020). Shadow education - Opportunity for development [Special issue]. European Journal of Education Research, Development and Policy, 55(3).

Hajar, A. (2018). Exploring Year 6 pupils' perceptions of private tutoring: Evidence from three mainstream schools in England. Oxford Review of Education, 44(4), 514-531. https://doi.org/10.1080/03054985. 2018.1430563.

Hajar, A. (2019). The association between private tutoring and access to grammar schools: Voices of Year 6 pupils and teachers in southeast England. British Educational Research Journal, 46(3), 459-479. https:// doi.org/10.1002/berj.3587.

Ireson, J., \& Rushforth, K. (2011). Private tutoring at transition points in the English education system: Its nature, extent and purpose, Research Papers in Education, 26, 1-19. https://doi.org/10.1080/ 02671520903191170.

Kalikova, S., \& Rakhimzhanova, Z. (2009). Private tutoring in Kazakhstan. In I. Silova (Ed.), Private supplementary tutoring in Central Asia: New opportunities and burdens (pp. 93-118). Paris: UNESCO International Institute for Educational Planning (IIEP).

Khaydarov, S. (2020). Shadow education in Uzbekistan: Teachers' perceptions of private tutoring in the context of academic lyceums. Orbis Scholae, 14(2), 81-104.

Kim, Y. C., \& Jung, J. (2019). Shadow education as worldwide curriculum studies. London: Palgrave Macmillan.

Kim, S., \& Lee, J. H. (2010). Private tutoring and demand for education in South Korea. Economic Development and Cultural Change, 58(2), 259-296. https://www.jstor.org/stable/10.1086/648186.

Kimura, H. (2018). Data-based discussion on education and children in Japan 2: Analyzing Juku - Another school after school [In Japanese]. https://www.crn.net.cn/research/201902224177563.html. Accessed March 2020. 
Kirby, P. (2016). Shadow schooling: Private tuition and social mobility in the UK. The Sutton Trust. Retrieved from http://www.suttontrust.com/wp-content/uploads/2016/09/Shadow-Schoolingformattedreport_FINAL.pdf.

Kodirov, S., \& Amonov, N. (2009). Private tutoring in Tajikistan. In I. Silova (Ed.), Private supplementary tutoring in Central Asia: New opportunities and burdens (pp. 136-161). Paris: UNESCO International Institute for Educational Planning (IIEP).

KOSIS (Korean Statistical Information Service). (2019). Participation rate on private education by school level and characteristics. http://kosis.kr/eng/statisticsList/statisticsListIndex.do? menuId=M_01_ 01\&vwcd=MT_ETITLE\&parmTabId=M_01_01\&statId=1963003\&themaId=\#SelectStatsBoxDiv . Accessed 10 September 2020.

Kyvik, S. (2009). The dynamics of change in higher education. Dordrecht: Springer.

Liu, J. (2018). Review of regulatory policies on private supplementary tutoring in China. ECNU Review of Education, 1(3), 143-153.

Liu, J., \& Bray, M. (2017). Determinants of demand for private supplementary tutoring in China: Findings from a national survey. Education Economics, 25(2), 205-218. https://doi.org/10.1080/09645292.2016. 1182623.

Loyalka, P., \& Zakharov, A. (2016). Does shadow education help students prepare for college? Evidence from Russia. International Journal of Educational Development, 49, 22-30.

Mahmud, R., \& Bray, M. (2017). School factors underlying demand for private supplementary tutoring in English: Urban and rural variations in Bangladesh. Asia Pacific Journal of Education, 37(3), 299-309.

NTC. (2018). Statistical data from the NTC website. National Testing Centre of Kazakhstan. http://www. testcenter.kz/ru/stats/stat/ent/2018/.

OECD. (2017). Higher education in Kazakhstan 2017. Reviews of national policies for education. Paris: OECD.

Prakhov, I., \& Sergienko, D. (2020). Matching between students and universities: What are the sources of inequalities of access to higher education? European Journal of Education, 55(2), 261-274.

Silova, I. (Ed.) (2009). Private supplementary tutoring in Central Asia. Paris: UNESCO International Institute for Educational Planning.

Silova, I. (2010). Private tutoring in Eastern Europe and Central Asia: Policy choices and implications. Compare: A Journal of Comparative and International Education, 40(3), 327-344.

Silova, I., Bray, M., \& Zabulionis, A. (2006). Methodological considerations. In I. Silova, B. Būdiene, \& M. Bray (Eds.), Education in a hidden marketplace: Monitoring of private tutoring (pp. 61-69). New York: Open Society Institute.

Št'astný, V., \& Kobakhidze, M. N. (2020). Throwing light on shadow education. Orbis Scholae, 14(2), 5-12. Trow, M. (1973). Problems in the transition from elite to mass higher education. Paris: OECD.

Van Manen, M. (1997). Researching lived experience: Human science for an action sensitive pedagogy. London: Althouse Press.

Yung, K. W. H., \& Bray, M. (2017). Shadow education: Features, expansion and implications. In T. K. C. Tse, \& M. Lee (Eds.), Making sense of education in post-handover Hong Kong: Achievements and challenges (pp. 95-111). London: Routledge.

Zhang, W., \& Bray, M. (Eds.). (2019). Private supplementary tutoring: Contexts, patterns, and developments [Special issue]. ECNU Review of Education, 2(1).

Zhang, W., \& Bray, M. (2020). Comparative research on shadow education: Achievements, challenges, and the agenda ahead. European Journal of Education, 55(3), 322-341. 


\section{APPENDIX A}

General information for all respondents.

\begin{tabular}{lcc}
\hline Gender & Age & Residential type \\
\hline$\square$ Male & & $\square$ Urban \\
$\square$ Female & ----------- years old & $\square$ Rural \\
\hline
\end{tabular}

1. Which school did you graduate from?

School name..................

Town/city. ...

2. Have you received the following types of tutoring in the past 2 years? (Tick all that apply) If ' $\mathrm{NO}$ ', you can finish the questionnaire at this stage.

$\square$ Private one-to-one

$\square$ Small group (less than 10 students)

No. of students:

$\square$ others (please specify) $\square$ Large group (10 or above students) No. of students:

$\square$ Online tutoring

$\square$ No tutoring

3. How long did you receive private tutoring?

$\square 3$ months or less

$\square$ 4-6 months

$\square$ 6-12 months

$\square$ 12-18 month

$\square 2$ years

4. In which subjects did you receive private tutoring during the last 2 years?

$\square$ Mathematics
$\square$ English
$\square$ Kazakh
$\square$ Russian

$\square$ Chemistry

$\square$ Physics

$\square$ Biology

$\square$ Others (please state) 
5. Why did you take private tutoring in the past 2 years? (Tick all that apply)

$\square$ I was preparing for university entrance exams

$\square$ I wanted to improve my exam scores at school

$\square$ I wanted to learn subjects better

$\square$ My parents chose it for me

Many of my classmates were doing it

My teachers recommended it

Others (please specify)

6. How much did private tutoring cost you on average per month?

20.000 tenge or less

20.000-40.000 tenge

$50.000-70.000$ tenge

$80.000-90.000$ tenge

100.000 tenge or more

7. If you are willing to take part in a follow-up interview, please write your email address here

\section{APPENDIX B}

\section{Selected interview questions}

Indicative interview protocol for students with PT.

1. Have you received private tutoring in the last two years? In what subject?

2. Why did you choose to take private tutoring? Who suggested it?

3. What did you learn in private lessons?

4. Did you enjoy private lessons? Were they useful? Why?

5. Are there any disadvantages of attending private lessons?

6. Did your parents know about your progress? What sort of things did they say?

7. Do you think private tutoring had an impact on your university placement? How?

8. What do you feel about the impact of tutoring on the wider society?

Open Access. This is an open-access article distributed under the terms of the Creative Commons Attribution-NonCommercial 4.0 International License (https://creativecommons.org/licenses/by-nc/4.0/), which permits unrestricted use, distribution, and reproduction in any medium for non-commercial purposes, provided the original author and source are credited, a link to the CC License is provided, and changes - if any - are indicated. 